\title{
Food taboos with socioeconomic status during pregnancy in West Kalimantan, Indonesia
}

\author{
Santy I. Putri ${ }^{* 1}$, Yefta $^{2}$, Astri Yunita ${ }^{3}$ \\ 1,2 Bagian Kebidanan, Universitas Tribhuwana Tungga Dewi, Malang \\ ${ }^{3}$ Bagian Kebidanan, Sekolah Tinggi Ilmu Kesehatan Bhakti Mulia, Kediri
}

DOI: 10.24252/al-sihah.v12i2.15943

Received: 14 September 2020 / In Reviewed: 16 September 2020 / Accepted: 23 September 2020 / Available online: 28 September 2020 (C) The Authors 2020. This is an open access article under the CC BY-NC-SA 4.0 license

\begin{abstract}
Each region in Indonesia has diversity in terms of food consumption patterns, especially for pregnant women, which is accompanied by beliefs about taboos from certain types of food. This study aimed to determine the relationship between age, education level, employment status, and the culture of food taboos in pregnant women. This was an observational analytic study with a cross-sectional approach. The study was conducted in the working area of the Bengkayang Health Center, West Kalimantan, Indonesia. A sample of 30 pregnant women selected by purposive sampling. The dependent variable is the culture of food taboos in pregnancy. The independent variables include age, education, and employment status. The data were collected by a questionnaire and analyzed using multiple linear regression. Education $(b=0.48 ; 95 \% C I=0.10$ to $0.85 ; p=0.015)$ and employment status ( $b=0.51 ; 95 \% C I=0.19$ to $0.84 ; p=0.003$ ) had a relationship with the culture of food taboos in pregnancy and were statistically significant. This study also found a relationship between education and employment status with the culture of food taboos in pregnancy.
\end{abstract}

Keywords: age; education; food taboos, pregnancy; sosioeconomic

\begin{abstract}
ABSTRAK
Setiap wilayah di Indonesia memiliki keanekaragaman dalam hal pola konsumsi makanan khususnya diperuntukkan kepada ibu hamil yang disertai dengan kepercayaan tentang pantang makan terhadap jenis makanan tertentu. Tujuan penelitian ini adalah untuk mengetahui hubungan antara usia, pendidikan, pekerjaan dan budaya pantang makan pada ibu hamil. Penelitian ini merupakan studi analitik observasional dengan rancangan cross-sectional. Lokasi penelitian di Wilayah Kerja Puskesmas Bengkayang, Kalimantan Barat, Indonesia. Besar sampel dalam penelitian ini sebesar $30 \mathrm{ibu}$ hamil dipilih dengan teknik purpossive sampling. Variabel dependen adalah budaya pantang makan ibu hamil. Variabel independen antara lain usia, pendidikan, dan pekerjaan. Pengumpulan data menggunakan kuesioner dan dianalisis menggunakan uji regresi linier berganda. Pendidikan $(b=0.48 ; 95 \% \mathrm{CI}=$ 0.10 to $0.85 ; \mathrm{p}=0.015)$ dan pekerjaan $(\mathrm{b}=0.51 ; 95 \% \mathrm{CI}=0.19$ to $0.84 ; \mathrm{p}=0.003)$ memiliki hubungan dengan budaya pantang makan ibu hamil dan secara statistik signifikan. Penelitian ini juga menemukan terdapat hubungan antara pendidikan dan pekerjaan dengan budaya pantang makan.
\end{abstract}

Kata kunci: budaya pantang makan; ibu hamil; pendidikan; sosioekonomi; usia

*Alamat Korespondensi:

Jl. Terusan Sigura-Gura D-124, Malang, Jawa Timur, 65146

Email: santyirene@gmail.com 


\section{PENDAHULUAN}

Kurang gizi berkaitan dengan morbiditas ibu dan kondisi kehamilan yang buruk (Alemu et al., 2019). Studi yang dilakukan di Asia Selatan menemukan bahwa perilaku konsumsi makanan tertentu pada ibu hamil, termasuk pembatasan asupan makanan yang disengaja, baik fisiologis maupun faktor sosiokultural, seperti keengganan konsumsi makanan jenis tertentu selama kehamilan, ketakutan yang terlalu besar akibat asupan makanan yang berlebihan, dan komplikasi kehamilan/ persalinan berkaitan dengan diet kehamilan yang tidak sehat. Demikian pula, penelitian di Nigeria telah mendokumentasikan pengaruh larangan makanan yang terikat budaya pada pembatasan konsumsi makanan yang disengaja selama kehamilan (Rosen et al., 2018).

Tabu terhadap makanan tertentu terutama di kalangan wanita di sub-Sahara Afrika, telah diidentifikasi sebagai salah satu faktor-faktor yang berkontribusi terhadap kekurangan gizi ibu selama kehamilan (Kariuki et al., 2017) (Pérez \& García, 2013). Menurut konsep UNICEF Food-Care Health, norma budaya, tabu, dan kepercayaan terletak di dalam faktor kontekstual yang menjadi penyebab dasar malnutrisi (Ekwochi et al., 2016). Hal tersebut kerena kekurangan asupan nutrisi, terutama selama kehamilan dan anak usia dini, dapat memiliki konsekuensi yang nyata un- tuk tumbuh kembang anak. Pada banyak komunitas, wanita hamil harus mengikuti beberapa hal yang berkaitan dengan tabu dan praktik budaya, yang memengaruhi makanan yang mereka konsumsi; dengan demikian, membuat wanita lebih rentan terhadap beberapa defisiensi mikronutrien, terutama vitamin A, folat, yodium, zat besi, kalsium dan seng, yang semuanya penting selama kehamilan (Suchdev et al., 2014). Sedangkan makanan yang kaya energi dan bergizi, seperti produk hewani, buahbuahan dan sayuran sangat penting untuk kesehatan baik ibu maupun janin yang sedang berkembang.

Sebuah penelitian melaporkan terdapat perilaku menghindari satu atau lebih makanan selama kehamilan berdasarkan pantangan makanan lokal (McNamara \& Wood, 2019) (Placek et al., 2017) (Chakrabarti \& Chakrabarti, 2019). Hal ini mirip dengan banyak penelitian yang dilaporkan di tempat lain bahwa wanita akan mematuhi berbagai tabu dan kepercayaan makanan, dengan beberapa makanan yang dijadikan pantangan adalah makanan bergizi yang dapat mengganggu nutrisi prenatal yang adekuat (Ugwa, 2016). Makanan yang paling sering dihindari selama kehamilan adalah produk daging (ayam, daging liar/semak dan daging merah), ikan, kentang, buah-buahan (jeruk dan buahbuahan lainnya yang identik dengan warna 
jeruk, persik, nanas dan jambu biji), kacang -kacangan, telur, butternut dan labu. Sebagian besar makanan yang dilaporkan sebagai makanan tabu adalah sumber kaya mikronutrien esensial (kacang-kacangan, telur, jeroan, semua buah-buahan, labu dan butternut), protein (daging semak, ikan, telur, ayam, jeroan dan kacang-kacangan) dan karbohidrat (kentang), yang sangat penting untuk kesehatan ibu dan perkembangan anak (Diana et al., 2018) (Zerfu et al., 2016).

Dilaporkan di tempat lain di beberapa negara Afrika dan Asia, di mana beberapa kelompok dibatasi makanannya selama kehamilan. Namun, alasan di balik menghindari konsumsi makanan ini berbeda-beda dalam komunitas tersebut. Misalnya, perempuan etnis Fulla di Gambia dilarang makan beberapa jenis makanan yang kaya akan karbohidrat, protein hewani dan mikronutrien selama kehamilan dengan berbagai alasan, yang berdampak terhadap terjadinya malnutrisi protein / kalori tinggi selama masa kanak-kanak dan kehamilan di negara tersebut (Pérez \& García, 2013). Gizi buruk selama kehamilan juga mengakibatkan banyak ibu berada pada peringkat tinggi risiko selama persalinan (Chakona \& Shackleton, 2019).

Tabu terhadap makanan tertentu diketahui pada hampir seluruh masyarakat di dunia, termasuk di Asia Tenggara
(Köhler et al., 2018). Sebagian besar agama menyatakan makanan tertentu sehat dan lainnya tidak layak untuk konsumsi manusia. Aturan dan regulasi diet mungkin mengatur secara khusus fase siklus hidup manusia dan dapat dikaitkan dengan peristiwa khusus seperti periode menstruasi, kehamilan, persalinan, menyusui, dan dalam masyarakat tradisional persiapan untuk berburu, berperang, pernikahan, dan pemakaman. Sebagai perbandingan, banyak pantangan makanan tampaknya tidak masuk akal sama sekali, seperti apa yang mungkin dinyatakan tidak layak oleh satu kelompok mungkin bisa diterima oleh kelompok lain. Di sisi lain, tabu pada makanan memiliki sejarah panjang dan orang mengharapkan penjelasan yang masuk akal untuk hal tersebut dalam konteks kebiasaan diet tertentu pada budaya tertentu. Namun, hal ini masih menjadi perdebatan pandangan dan tidak ada teori yang dapat menjelaskan mengapa orang menerapkan tabu pada makanan (Meyer-Rochow, 2009).

Budaya lain juga mengembangkan pantangan makanan pada wanita hamil terjadi pada wanita di Tionghoa, Hong Kong, antara lain makan udang karena akan menyebabkan alergi kulit, daging kelinci, yang akan menyebabkan bibir sumbing pada bayi baru lahir dan daging sapi yang juga akan mempengaruhi kesehatan janin (Arzoaquoi et al., 2015). Rasa takut tidak 
mengikuti kepercayaan tradisional adalah hal yang biasa. Mereka menyatakan bahwa mereka merasa tidak nyaman jika tidak mematuhi ritual ini. Sebuah penelitian di Limpopo Afrika Selatan ditemukan bahwa untuk mencegah malformasi janin, yang bisa dilakukan oleh orang-orang, wanita hamil mebutuhkan dukungan secara lahir dan batin dan juga perlu diperkuat dengan makanan herbal. Perspektif yang menarik menyatakan bahwa di kalangan perempuan, adat, tabu dan izin selama siklus reproduksi sangat terkait dengan dimensi ruang alam yang sakral dan terkait pengetahuan, praktik dan ritual (Agus et al., 2012).

Beberapa hasil studi terkait dengan budaya pantang makan di Indonesia, salah satunya di Kabupaten Jepara, Jawa Tengah yang menjelaskan bahwa selama masa kehamilan, ibu hamil memiliki keyakinan untuk menjaga Kesehatan diri dan janinya serta dapat melahirkan bayi dengan selamat maka terdapat beberapa makanan yang pantang untuk dikonsumsi seperti kepiting, udang dan buah nanas (Suryawati, 2007). Selain itu, studi lain juga menemukan bahwa budaya pantang makan juga dilakukan oleh ibu hamil di Suku Tengger Kabupaten Malang, Jawa Timur. Beberapa makanan yang menjadi pantangan selama kehamilan antara lain pisang rajamala, nanas, salak, mangga kweni, nangka, durian, lele, kubis, serta beberapa makanan tertentu yang di- anggap dapat mengganggu kesehatan ibu hamil beserta janin yang dikandungnya (Sholihah et al., 2014). Penelitian yang dilaksanakan di Kupang, NTT pada suku Atoni didapatkan bahwa ibu hamil memiliki beberapa makanan pantangan yaitu tidak boleh makan jagung pipil, kerak nasi dan telur serta daging yang dibunuh. Pantang makanan yang dilakukan oleh ibu hamil juga ditemui pada masyarakat Toraja, Sulawesi Selatan antara lain daging, nanas, jantung pisang, serta ikan asin (Kencanawati, 2016).

Melalui kajian beberapa wilayah di Indonesia yakni Jawa Tengah, Jawa Timur, Nusa Tenggara Timur, serta Sulawesi Selatan menunjukkan bahwa keragaman budaya dalam hal pantang makanan tertentu yang dipercaya oleh ibu hamil diyakini dapat menjaga kesehatan ibu beserta janinnya justru dapat memberikan dampak negatif akibat kebutuhan nutrisi yang tidak terpenuhi. Penelitian dari beberapa negara tersebut membuktikan bahwa di setiap negara terdapat budaya pantang makanan yang berbeda-beda, termasuk di Indonesia yang memiliki keragaman suku, budaya serta adat-istiadat.

Kabupaten Bengkayang merupakan salah satu wilayah dengan budaya yang berlimpah serta unik jika dibandingkan dengan wilayah lain. Pada tahun 2014 pemerintah Kabupaten Bengkayang berencana membu- 
at kampung budaya Bengkayang sebagai miniatur keragaman adat yang ada di Provinsi Kalimantan Barat. Pada tahun 2019 Bengkayang menerima penghargaan sebagai kampung adat terbaik se-Indonesia. Hal tersebut menarik minat peneliti untuk melaksanakan studi yang terkait dengan budaya masyarakat setempat khususnya ibu hamil dalam hal budaya yang terkait dengan pantang makanan selama masa kehamilan. Penelitian ini bertujuan untuk mengetahui hubungan antara usia, pendidikan, serta status pekerjaan dan budaya pantang makanan pada ibu hamil di wilayah kerja Puskesmas Bengkayang, Kalimantan Barat.

\section{METODE PENELITIAN}

Penelitian ini merupakan penelitian analitik observasional dengan desain studi cross-sectional. Penelitian dilaksanakan di Wilayah Kerja Puskesmas Bengkayang, Kalimantan Barat pada bulan Agustus 2020. Teknik sampel yang digunakan dalam pengambilan sampel yakni purpossive sampling karena peneliti memerlukan kriteria khusus agar sampel yang diambil sesuai dengan tujuan penelitian. Kriteria inklusi dalam penelitian ini yakni ibu hamil di Puskesmas Bengkayang yang memiliki kepercayaan terhadap budaya pantang makan tertentu. Jumlah populasi dalam penelitian ini adalah $44 \mathrm{ibu}$ hamil trimester 1-3. Ru- mus yang digunakan untuk mengetahui jumlah sampel yaitu dengan menggunakan rumus Lemeshow, diperoleh hasil jumlah sampel sebesar 30 responden. Instrumen pengambilan data yang digunakan dalam penelitian ini adalah kuesioner budaya pantang makan pada ibu hamil dengan item pertanyaan masing-masing diambil dari tinjauan pustaka sebagai sumber dan dilaksanakan uji reliabilitas menggunakan alpha cronbach's dengan SPSS. Data yang telah dikumpulkan terlebih dahulu diuji normalitasnya menggunakan uji shapiro wilk dengan bantuan SPSS. Data yang telah melalui uji normalitas kemudian dianalisis menggunakan regresi linier berganda dengan bantuan SPSS.

\section{HASIL PENELITIAN}

Tabel 1 menunjukkan bahwa usia yang paling dominan dalam penelitian ini adalah usia 20-35 tahun yakni sebanyak 19 ibu hamil (63.3\%) dan usia ibu hamil yang paling rendah terlibat dalam penelitian ini yakni $>35$ tahun sebanyak 5 orang (16.7 $\%$ ). Sebagian besar sampel penelitian berlatar belakang pendidikan SD sejumlah 15 ibu hamil (50\%) serta keterlibatan terendah ibu hamil dengan pendidikan terakhir SMA sejumlah 6 orang (20\%). Status pekerjaan yang dominan yakni IRT sebanyak 24 ibu hamil $(80 \%)$. Ibu hamil yang bekerja di bidang swasta memiliki jumlah terkecil 
yakni 2 orang $(13.3 \%)$.

Berdasarkan tabel 2 dapat diketahui besar koefisien regresi untuk variabel usia bertanda negatif, berarti dengan usia yang semakin meningkat tidak memiliki keterkaitan dengan menurunnya perilaku status pekerjaan bertanda positif, berarti dengan pekerjaan yang semakin baik memiliki keterkaitan dengan peningkatan perilaku untuk menghindari budaya pantang makan. Nilai b sebesar 0.51 menunjukkan bahwa apabila nilai pekerjaan dapat diting-

Tabel 1. Distribusi Karakteristik Responden

\begin{tabular}{lccc}
\hline Karakteristik & Kriteria & $\mathbf{n}$ & $\mathbf{\%}$ \\
\hline \multirow{2}{*}{ Usia } & $<20$ & 6 & 20 \\
& $20-35$ & 19 & 63.3 \\
\multirow{3}{*}{ Pendidikan } & $>35$ & 5 & 16.7 \\
& & & \\
& SD & 15 & 50 \\
\multirow{2}{*}{ Status pekerjaan } & SMP & 9 & 30 \\
& SMA & 6 & 20 \\
& & & 80 \\
& IRT & 24 & 36.7 \\
\hline
\end{tabular}

Sumber: Data Primer, 2020

menghindari budaya pantang makan. Nilai b sebesar -0.03 menunjukkan bahwa tidak ada hubungan antara usia dan budaya pantang makan serta secara statistik tidak signifikan.

Besar koefisien regresi untuk variabel pendidikan bertanda positif, berarti pendidikan yang semakin tinggi terkait dengan peningkatan perilaku menghindari budaya pantang makan. Nilai $b$ sebesar 0.48 menunjukkan bahwa apabila nilai pendidikan dapat ditingkatkan satu unit, maka perilaku menghindari budaya pantang makan akan bertambah sebesar 0.48 berarti ada hubungan positif antara pendidikan dan budaya pantang makan dan secara statistik signifikan.

Besar koefisien regresi untuk variabel katkan satu unit, maka perilaku menghindari budaya pantang makan akan bertambah sebesar 0.51 berarti ada hubungan positif antara pekerjaan dan budaya pantang makan dan secara statistik signifikan.

\section{PEMBAHASAN}

Masyarakat Indonesia tidak terlepas dari adat-istiadat yang diturunkan secara turun temurun dan menjadi suatu kebiasaan. Salah satunya yakni pantang makanan tertentu pada beberapa ibu hamil yang hampir ada di setiap daerah. Berdasarkan hasil penelitian, diketahui bahwa budaya pantang makan memiliki korelasi yang signifikan dengan pendidikan dan pekerjaan. Se- 
dangkan usia tidak berkorelasi dengan budaya pantang makan di Wilayah Kerja Puskesmas Bengkayang, Kalimantan Barat. Namun budaya pantang makan ini tidak seluruhnya berdampak positif terhadap kesehatan, bahkan dapat memberikan dam- siapnya tubuh ibu dalam proses persalinan, sehingga menjadi lebih sulit dan berjalan dalam jangka waktu lama. Bahkan dalam beberapa kondisi dapat meningkatkan risiko bayi lahir prematur, serta dapat meningkatkan Angka Kematian Ibu (AKI).

Tabel 2. Analisis Multivariat

\begin{tabular}{|c|c|c|c|c|}
\hline \multirow{2}{*}{ Variabel independen } & \multirow{2}{*}{$\mathbf{b}$} & \multicolumn{2}{|c|}{ CI $95 \%$} & \multirow{2}{*}{$\mathbf{p}$} \\
\hline & & Batas bawah & Batas atas & \\
\hline Usia & -0.03 & -0.08 & 0.02 & 0.264 \\
\hline Pendidikan & 0.48 & 0.10 & 0.85 & 0.003 \\
\hline Status Pekerjaan & 0.51 & 0.19 & 0.84 & 0.029 \\
\hline \multicolumn{5}{|l|}{ Jumlah sampel $=30$} \\
\hline \multicolumn{5}{|l|}{ Adj R-Squared $=0.35$} \\
\hline $\mathrm{p}=<0.001$ & & & & \\
\hline
\end{tabular}

Sumber: Data Primer, 2020

pak buruk terhadap kesehatan ibu hamil dan janin. Perilaku pantang makan pada ibu hamil akan berpengaruh terhadap jumlah asupan nutrisi untuk ibu dan janin, serta memberikan dampak yang tidak baik untuk persiapan proses melahirkan. Beberapa budaya pantang makanan justru mengurangi asupan nutrisi yang penting, sehingga akan menimbulkan masalah kesehatan, antara lain kekurangan Energi Kronik (KEK) dan anemia pada ibu hamil, menurunnya asupan nutrisi (terutama sumber protein) dapat mengakibatkan gizi kurang yang akan memicu timbulnya komplikasi, seperti perdarahan, anemia, berat badan ibu hamil yang tidak sesuai dengan berat normalnya, serta dapat memicu penyakit infeksi, proses persalinan tidak berjalan dengan baik, KEK yang selanjutnya mengakibatkan kurang
Hasil penelitian ini tidak sejalan dengan penelitian yang dilakukan oleh $\mathrm{Ug}$ wa (2016) yang menyatakan bahwa tidak terdapat korelasi antara pendidikan dan budaya pantang makan pada ibu hamil. Namun, penelitian ini sejalan dengan hasil studi yang dilakukan oleh Demissie (2017) bahwa pendidikan memiliki korelasi yang erat dengan budaya pantang makan. Semakin rendah pendidikan, maka semakin besar kemungkinan mereka menjadi miskin dan pada saat yang sama akan semakin meningkat budaya pantang makanan yang akan mereka lakukan.

Berdasarkan hasil penelitian, pendidikan memiliki korelasi dengan budaya pantang makan ibu hamil yang secara statistik signifikan. Pendidikan akan mempengaruhi pengetahuan gizi. Suatu penelitian perilaku 
diet wanita hamil di Ethiopia membuktikan bahwa kurangnya pengetahuan gizi selama kehamilan akibat pendidikan yang rendah berkorelasi terhadap pola makan wanita tersebut selama hamil (Yoseph, 2015). Apabila ibu hamil dengan tingkat pendidikan yang rendah mempercayai budaya pantang makan terhadap jenis makanan tertentu maka dapat menghambat pertumbuhan janin yang dikandungnya. Asupan nutrisi yang tidak mencukupi pada ibu hamil berdampak terhadap kejadian kurang gizi bagi janin. Hal ini akan meningkatkan risiko kematian neonatal, abortus, cacat bawaan, asfiksia intra partum (mati dalam kandungan), anemia pada bayi, serta bayi dengan berat badan lahir rendah (BBLR).

Hasil studi yang dilakukan oleh Demilew (2020) menyatakan bahwa pengetahuan tentang pembatasan makanan selama kehamilan memiliki peran sentral dalam menentukan praktik pembatasan makanan wanita. Dalam studi ini disebutkan praktik pembatasan makanan akan meningkat sesuai dengan peningkatan pengetahuan ibu tentang pembatasan makanan selama kehamilan. Responden dalam penelitian tersebut sebagian besar memiliki tingkat pendidikan yang rendah, sehingga tingkat melek huruf mereka menjadi penghalang untuk mengakses informasi terkait pemenuhan nutrisi selama masa kehamilan. Berbagai risiko kesehatan dipengaruhi oleh ku- rangnya pengetahuan ibu yang berkaitan juga dengan tingkat pendidikan, semakin tinggi pendidikan yang dimiliki oleh ibu, maka pengetahuan tentang zat gizi yang harus dipenuhi selama hamil akan semakin baik. Tingkat pendidikan akan mempengaruhi pola makan terutama pada ibu hamil yang dipengaruhi oleh kepercayaan terhadap pantangan pada beberapa makanan tertentu merupakan suatu budaya, kebiasaan, atau bahkan anjuran yang melarang untuk mengonsumsi makanan tertentu misalnya sayuran, ikan, buah, serta makanan lainnya karena dianggap dapat berdampak pada kesehatan, terutama pada janin yang dikandung ibu hamil. Hal tersebut menurut keyakinan ibu hamil bertujuan untuk menjaga kesehatan ibu beserta bayi yang dikandungnya, akan tetapi pemahaman yang keliru mengenai hal ini justru membahayakan kesehatan terkait dengan kurangnya asupan zat gizi yang dibutuhkan selama masa kehamilan.

Penelitian yang dilakukan oleh Intan (2018) menyatakan bahwa tabu makanan mengacu pada makanan yang dilarang keras untuk alasan kesehatan, budaya dan agama. Hal yang tabu ini diterapkan pada beberapa individu yang paling rentan, termasuk wanita dan anak-anak, dan sering kali berpusat pada makanan yang berasal dari hewan, yang biasanya bagus sumber protein. Di Ethiopia, pantangan makanan dianggap 
telah ditetapkan selama kehamilan sebagai sarana perlindungan kesehatan wanita dan bayinya. Namun demikian, cukup jelas bahwa pembatasan makanan ekstensif lebih cenderung membahayakan kesehatan ibu dan bayi. Malnutrisi adalah masalah kesehatan yang signifikan mempengaruhi wanita hamil di Ethiopia dan memiliki konsekuensi serius untuk kehamilan dan kelahiran. Oleh karena itu, pantangan makanan terkait erat dengan nutrisi status wanita hamil Etiopia, yang memengaruhi kesehatan mereka dan bayinya (Vasilevski \& Carolan-Olah, 2016).

Hasil studi yang dilakukan oleh Yeneabat et al. (2019) menemukan bahwa wanita hamil yang memiliki tingkat pekerjaan lebih rendah berkorelasi dengan pemenuhan nutrisi yang dikaitkan dengan tabu terhadap makanan. Pekerjaan merupakan suatu kegiatan yang bermaksud untuk memperoleh imbalan berupa gaji atau upah. Pekerjaan menghasilkan pendapatan, yang meningkatkan kapasitas pembelian dan memungkinkan akses ke makanan, perawatan kesehatan, dan kebutuhan lainnya (Singh et al., 2020). Sejalan dengan penelitian yang dilakukan oleh (Thornton et al., 2013) menemukan bahwa status pekerjaan merupakan salah satu dari banyak faktor yang dapat mempengaruhi korelasi antara jenis pekerjaan dengan perilaku makan wanita. Namun, penelitian ini juga tidak sejalan dengan studi yang dilakukan oleh Ekwochi et al. (2016) yang mengemukakan bahwa tidak terdapat korelasi antara pekerjaan dengan perilaku menghindari makanan tertentu karena pantangan makanan pada masa kehamilan.

Dalam penelitian ini, didapatkan hasil bahwa terdapat korelasi yang signifikan antara pekerjaan dengan budaya pantang makan. Semakin tinggi tingkat pekerjaan seorang ibu hamil, maka perilaku untuk menghindari pantang makan semakin meningkat. Hal tersebut dapat dipengaruhi oleh factor lingkungan pekerjaan, apabila budaya di lingkungan setempat mendukung budaya pantang makan ibu hamil, maka akan mempengaruhi perilaku seseorang.

Usia dalam penelitian ini tidak memiliki hubungan yang signifikan dengan budaya pantang makan. Sesuai dengan studi yang dilakukan oleh Grossmann et al. (2012) baik usia muda ataupun tua tidak menunjukkan adanya perbedaan pengetahuan mengenai budaya. Hasil studi lain mengemukakan bahwa interaksi antara usia dan budaya dapat dipengaruhi oleh kognitif seseorang, hal tersebut terkait dengan perbedaan budaya di antara orang dewasa tua dengan orang dewasa yang lebih muda (Na et al., 2017). Terdapat banyak factor yang dapat mempengaruhi ibu hamil dalam hal budaya pantang makan antara lain adat istiadat dari nenek moyang yang sudah 
turun-temurun, keterpaparan informasi, penghasilan, serta faktor lainnya.

\section{KESIMPULAN}

Hasil penelitian memberikan interpretasi akhir bahwa usia ibu hamil tidak memiliki korelasi dengan budaya pantang makan. Hal tersebut dapat diakibatkan oleh beberapa factor lain yang menentukan budaya pantang makan pada ibu hamil antara lain keterpaparan infromasi, adat istiadat yang turun temurun, penghasilan yang dimiliki oleh keluarga, dan lain sebagainya. Sehingga meskipun semakin bertambah usia ibu hamil tersebut tidak memiliki keterkaitan dengan budaya pantang makan. Budaya pantang makan memiliki korelasi dengan pendidikan dan pekerjaan dengan arah hubungan positif, yang bermakna bahwa semakin tinggi tingkat pendidikan ibu hamil, maka budaya untuk menghindari pantang makan akan semakin baik. Demikian juga dengan pekerjaan yang semakin baik, maka budaya menghindari pantang makan pada ibu hamil akan semakin meningkat. Dalam penelitian ini terdapat beberapa keterbatasan antara lain dalam pengumpulan data yang dilaksanakan secara online, peneliti hanya dapat menjangkau $30 \mathrm{ibu}$ hamil, dengan proses interview menggunakan video call yang terbatas oleh karena tidak dapat berinteraksi secara langsung selama masa pandemic, selain itu peneliti juga memiliki keterbatasan dalam hal literatur yang digunakan karena variabel penelitian yang diteliti masih jarang ditemukan dalam jurnal -jurnal Indonesia. Hasil penelitian ini diharapkan dapat mendorong kerjasama lintas tenaga kesehatan dan lintas sektor untuk bersama-sama memberikan perhatian terhadap kebutuhan dasar nutrisi ibu hamil mengingat ibu hamil yang nantinya akan melahirkan generasi penerus bangsa karena generasi yang berkualitas berawal dari kondisi ibu hamil yang optimal.

\section{SARAN}

Bagi ibu hamil disarankan dari hasil penelitian ini yang memiliki budaya pantang makan terhadap jenis makanan tertentu dapat menghentikan atau menghindari hal tersebut agar kebutuhan nutrisi bagi ibu hamil dan janin dapat terpebuhi, sehingga kesehatan ibu dan janin dapat terjaga hingga persalinan nanti. Bagi peneliti selanjutnya disarankan untuk dapat membandingkan budaya pantang makan pada beberapa wilayah di Indonesia mengingat Indonesia memiliki keragaman budaya dan adat istiadat dengan variabel penelitian yang belum/ masih jarang diteliti. Bagi institusi kesehatan disarankan agar dapat meningkatkan kualitas pendidikan terhadap calon tenaga kesehatan salah satunya melalui program pendidikan yang memasukkan nilai budaya terkait dengan kebutuhan nutrisi ibu 
hamil.

\section{DAFTAR PUSTAKA}

Agus, Y., Horiuchi, S., \& Porter, S. E. (2012). Rural Indonesia women's traditional beliefs about antenatal care. BMC Research Notes, 5(1), 1. https://doi.org/10.1186/1756-0500-5589

Alemu, F. M., Fuchs, M. C., Vitale, T. M., \& Salih, M. A. M. (2019). severe maternal morbidity (near-miss) and its correlates in the world's newest nation: south sudan. International journal of women's health, 11, 177. https://dx.doi.org/10.2147\%

2FIJWH.S160022

Arzoaquoi, S. K., Essuman, E. E., Gbagbo, F. Y., Tenkorang, E. Y., Soyiri, I., \& Laar, A. K. (2015). Motivations for food prohibitions during pregnancy and their enforcement mechanisms in a rural Ghanaian district. Journal of Ethnobiology and Ethnomedicine, 11(1), 1-9. https://doi.org/10.1186/ s13002-015-0044-0

Chakona, G., \& Shackleton, C. (2019). Food Taboos and Cultural Beliefs Influence Food Choice and Dietary Preferences among Pregnant. Nutrients, 11, 1-18. https:// doi.org/10.3390/nu11112668

Chakrabarti, S., \& Chakrabarti, A. (2019). Food taboos in pregnancy and early lactation among women living in a rural area of West Bengal. Journal of Family Medicine and Primary Care, $8(1), \quad 86 . \quad$ https:// dx.doi.org/10.4103\%

2Fjfmpc.jfmpc_53_17=

Demilew, Y. M., Alene, G. D., \& Belachew, T. (2020). Effect of guided counseling on dietary practices of pregnant women in West Gojjam Zone, Ethiopia. PLoS ONE, 15(5), $1-11$.

https://doi.org/10.1371/journal.pone. 0233429

Demissie, T., \& Kogi-Makau, W. (1998). Food taboos among pregnant women in Hadiya Zone, Ethiopia. The Ethiopian Journal of Health Development (EJHD), 12(1). 2-8. https://www.ejhd.org/index.php/ejhd /article/ download/934/689/

Diana, R., Rachmayanti, R. D., Anwar, F., Khomsan, A., Christianti, D. F., \& Kusuma, R. (2018). Food taboos and suggestions among Madurese pregnant women: a qualitative study. Journal of Ethnic Foods, 5(4), 246-253.

https://doi.org/10.1016/j.jef.2018.10. 006

Ekwochi, U., Osuorah, C. D. I., Ndu, I. K., Ifediora, C., Asinobi, I. N., \& Eke, C. B. (2016). Food taboos and myths in South Eastern Nigeria: The belief and practice of mothers in the region. Journal of Ethnobiology and Ethnomedicine, 12(1), 1-6. https://doi.org/10.1186/s13002-0160079-x

Grossmann, I., Karasawa, M., Izumi, S., Na, J., Varnum, M. E. W., Kitayama, S., \& Nisbett, R. E. (2012). Aging and Wisdom: Culture Matters. Psychological Science, 23(10), 1059 1066.

https://doi.org/10.1177/09567976124 46025

Intan, T. (2018). Fenomena Tabu Makanan Pada Perempuan Indonesia Dalam Perspektif Antropologi Feminis. PALASTREN Jurnal Studi Gender, 11(2), 233-258. https://10.21043/palastren.v11i2.375 7 
Kariuki, L. W., Lambert, C., Purwestri, R. C., Maundu, P., \& Biesalski, H. K. (2017). Role of food taboos in energy, macro and micronutrient intake of pregnant women in western Kenya. Nutrition and Food Science, 47(6), 795-807.

https://doi.org/10.1108/NFS-092016-0146

Kencanawati, D. A. P. M. (2016). Kehamilan Dalam Pandangan Budaya Timor (Atoni) Dewa Ayu Putu Mariana Kencanawati. Info Kesehatan, 14(12), 1195-1206.

http://jurnal.poltekeskupang.ac.id/ind ex.php/infokes/article/download/107/ 104

Köhler, R., Sae-tan, S., Lambert, C., \& Biesalski, H. K. (2018). Plant-based food taboos in pregnancy and the postpartum period in Southeast Asia - a systematic review of literature. Nutrition \& Food Science. http://doi.org/10.1108/nfs-02-20180059

McNamara, K., \& Wood, E. (2019). Food taboos, health beliefs, and gender: understanding household food choice and nutrition in rural Tajikistan. Journal of Health, Population and Nutrition, 38(1), 17. https://doi.org/10.1186/s41043-0190170-8

Meyer-Rochow, V. B. (2009). Food taboos: Their origins and purposes. Journal of Ethnobiology and Ethnomedicine, 5 , $1-10$. https://doi.org/10.1186/1746-4269-518

Na, J., Huang, C. M., \& Park, D. C. (2017). When age and culture interact in an easy and yet cognitively demanding task: Older adults, but not younger adults, showed the expected cultural differences. Frontiers in Psychology,
8(MAR), 1-11.

https://doi.org/10.3389/fpsyg.2017.00 457

Pérez, G. M., \& García, A. P. (2013). Nutritional Taboos among the Fullas in Upper River Region, The Gambia. Journal of Anthropology, 2013, 1-9. https://doi.org/10.1155/2013/873612

Placek, C. D., Madhivanan, P., \& Hagen, E. H. (2017). Innate food aversions and culturally transmitted food taboos in pregnant women in rural southwest India: Separate systems to protect the fetus?. Evolution and Human Behavior, 38(6), 714-728. https://doi.org/10.1016/j.evolhumbeh av.2017.08.001

Rosen, J. G., Clermont, A., Kodish, S. R., Matar Seck, A., Salifou, A., Grais, R. F., \& Isanaka, S. (2018). Determinants of dietary practices during pregnancy: A longitudinal qualitative study in Niger. Maternal and Child Nutrition, 14(4), 1-10. https://doi.org/10.1111/mcn.12629

Singh, D. R., Ghimire, S., Upadhayay, S. R., Singh, S., \& Ghimire, U. (2020). Food insecurity and dietary diversity among lactating mothers in the urban municipality in the mountains of $\mathrm{Ne}$ pal. PloS one, 15(1), e0227873. https://10.1371/journal.pone.0227873

Sholihah, L. A., Ayu, R., \& Sartika, D. (2014). Makanan Tabu pada Ibu Hamil Suku Tengger Food Taboo among Pregnant Women of Tengger Tribe. Jurnal Kesehatan Masyarakat Nasional, 8(7), 319-324. https://10.21109/kesmas.v0i0.372

Suchdev, P. S., Peña-Rosas, J. P., \& DeRegil, L. M. (2014). Multiple micronutrient powders for home (point-ofuse) fortification of foods in pregnant women. Cochrane Database of Sys- 
tematic Reviews, 2014(6). https://doi.org/10.1002/14651858.CD 011158

Suryawati, C. (2007). Faktor sosial budaya dalam praktik perawatan kehamilan, persalinan, dan pasca persalinan (Studi di Kecamatan Bangsri Kabupaten Jepara). Jurnal Promosi Kesehatan Indonesia, 2(1), 21-31. . https://doi.org/10.14710/jpki.2.1.2131

Thornton, L. E., Lamb, K. E., \& Ball, K. (2013). Health \& Place Employment status, residential and workplace food environments: Associations with women' s eating behaviours. Health \& Place, 24, 80-89. https://doi.org/10.1016/j.healthplace. 2013.08.006

Ugwa, E. (2016). Nutritional Practices and Taboos Among Pregnant Women Attending Antenatal Care at General Hospital in Kano, Northwest Nigeria. Annals of Medical and Health Sciences Research, 6(2), 109-114. https://doi.org/10.4103/21419248.181846

Vasilevski, V., \& Carolan-Olah, M. (2016). Food taboos and nutrition-related pregnancy concerns among Ethiopian women. Journal of Clinical Nursing,
25(19-20),

3069-3075.

https://doi.org/10.1111/jocn.13319

Yeneabat, T., Adugna, H., Asmamaw, T., Wubetu, M., Admas, M., Hailu, G., Amare, T. (2019). Maternal dietary diversity and micronutrient adequacy during pregnancy and related factors in East Gojjam Zone, Northwest Ethiopia, 2016. BMC Pregnancy and Childbirth, 19(1), 1-9. https://doi.org/10.1186/s12884-0192299-2

Yoseph, H. H. (2015). Prevalence of food aversions, cravings and pica during pregnancy and their association with nutritional status of pregnant women in Dale Woreda, Sidama zone, SNNPRS, Ethiopia. International Journal of Nutrition and Metabolism, 7(1), 1-14. https://doi.org/10.5897/ijnam2014.01 62

Zerfu, T. A., Umeta, M., \& Baye, K. (2016). Dietary habits, food taboos, and perceptions towards weight gain during pregnancy in Arsi, rural central Ethiopia: a qualitative crosssectional study. Journal of Health, Population and Nutrition, 35(1), 1-7. https://doi.org/10.1186/s41043-0160059-8 